\title{
Characteristics of meat packaging materials and their environmental suitability assessment
}

\author{
Danijela Z. Šuput ${ }^{1}$, Vera L. Lazić ${ }^{1}$, Ljubinko B. Lević ${ }^{1}$, Nevena M. Krkić ${ }^{1}$, Vladimir M. Tomović ${ }^{1}$, Lato L. Pezo ${ }^{2}$ \\ ${ }^{1}$ University of Novi Sad, Faculty of Technology, Novi Sad, Serbia \\ ${ }^{2}$ University of Belgrade, Institute of General and Physical Chemistry, Belgrade, Serbia
}

\begin{abstract}
After the functional phase, packaging becomes waste that is recycled or disposed of in landfills. Recently, numerous packages have been developed for assessing the packaging risk on the environment. We applied GaBi 4 Education software on polymer product packaging for meat products. The objective of the first part of the paper was characterization of materials used for meat and meat products packaging in terms of mechanical and barrier properties. The results showed that the tested materials were able to keep a protective atmosphere and contribute to the quality and sustainability of the product. Air permeability was 3.60 and $26.60 \mathrm{ml} \mathrm{m}^{-2} / 24 \mathrm{~h}$, and water vapor permeability was 6.90 and $9.50 \mathrm{ml}$ $\mathrm{m}^{-2} / 24 \mathrm{~h}$, respectively, for foils 1 and 2 , as a result of different film composition. In the second part, based on real data, GaBi 4 Education software was applied. The obtained results showed that organic compounds emissions had the highest impact on human health and the most damaging environmental impact observed was the emission of $\mathrm{CO}_{2}$.
\end{abstract}

Keywords: materials and packaging, environmental impact, meat products.

PROFESSIONAL PAPER

UDC 637.5:621.798:54

Hem. Ind. 67 (4) 615-620 (2013)

doi: 10.2298/HEMIND120907104S

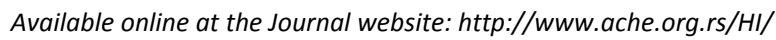

One of the main challenges for the European Union is to reach sustainable development [1] because one of the main negative consequences of "plastic revolution“ is the often-emphasised question of plastic waste disposal. This is why packaging has been targeted as one of the most severely polluting activities. As a result, many countries around the world now have measures in place aiming at reduction of packaging waste [2]. A Life Cycle Assessment (LCA) is generally considered the best environmental management tool that can be used to to define designing and operating criteria able to make a programme of recycling and recovery of plastics, economically affordable, and, at the same time, socially acceptable and environmentally effective $[3,4]$. By a definition LCA is a process ,to evaluate environmental burdens related to products, processes or activities, to identify potential impacts on the environment coming from energy or material consumptions, to identify and to evaluate possible product improvements" [5]. LCA is a methodology for quantifying the potential environmental impacts associated with a product, process or activity. This method has become an important tool for authorities and industries in order to compare alternative products, processes or services [6] and to identify environmental and critical points where the environmental management system should be improved. LCA has a wide-rang-

Correspondence: D.Z. Šuput, University of Novi Sad, Faculty of Technology, Bulevar Cara Lazara 1, 21000 Novi Sad, Serbia.

E-mail: suput.danijela@gmail.com

Paper received: 7 September, 2012

Paper accepted: 24 October, 2012 ing application in decision making, product and process design, research and development, purchasing, information for defining company strategies, identification of areas of improvement, selection of environmental indicators, environmental labeling and ecological product statement [7].

LCA is an ISO standardized method [8-11]. The four steps characterizing a general application of LCA, as defined in the UNI EN ISO 14040 norm, are: definition of goal and scope, inventory analysis, impact assessment and interpretation. Such steps do not describe a static process - they use feedback operation to finetune initial objectives and to enable the quality of final results to be improved [12]. The aim of LCA is to provide a picture of an activity and its interaction with the environment at the present level of knowledge; contribute to the understanding of the overall and independent nature of the environmental consequences of human activities; provide decision makers with information about possible environmental improvements [2].

The two most commonly used systems chosen in LCA studies are "cradle-to-factory gate" and "cradle-tograve“. A "cradle-to-factory gate" LCA study includes steps from the extraction of raw materials and fuels, conversion steps up and until the product is delivered at the factory gate (published by material producers). The system "cradle-to-grave" covers all steps of the system "cradle-to-factory gate" and in addition, the usage and the disposal phase [13]. Nevertheless, depending on the specific requirements, LCA may also be used in a limited perspective (from „process-toprocess" or from "gate-to-gate“), which can be of par- 
ticular interest if the limited part of the whole life cycle should be analysed [12].

In recent years, several LCA studies have focused on food products, such as basic carbohydrate food (bread, potatoes, rice and pasta), fruit and vegetables, dairy products, meat products, fish production and processing [14] as well as canned tuna fish [15], cooked dish [16], ready meals sector [7], but not meat and meat products.

The variables that influence shelf life properties of packaged meat are product type, gas mixture, package and headspace, packaging equipment, storage temperature and additives [17]. Traditionally, the plastic films used for vacuum and modified atmosphere packaging (MAP), techniques that are used in the meat industry to extend the product shelf-life [18], were developed to improve their gas and moisture barriers, shrinking properties, sealing characteristics, cook-in and retort capability and a variety of print and color options. McMillin briefly reviews materials that could be used as packaging [19]. The use of multilayered film including a barrier layer might not be desirable in respect to recycling issues. Any assessment of the environmental impact of food packaging must consider the positive benefits of reduced food waste in the supply chain. Food packaging accounted for almost $2 / 3$ of total packaging waste by volume and food packaging accounted for about $50 \%$ by weight of total packaging sales.

In this work, we sampled packaging materials and recorded all necessary data from real system related to packaging process, distribution, sale, meat consumption and packaging disposal, with the aim of applying LCA analysis in order to evaluate damaging system points for the environment.

\section{EXPERIMENTAL}

Film samples were provided by a national company that produces meat products and wished to stay anonymous because they import packaging materials. Film samples had different composition: transparent PVC// //PE-EVOH-PE, that forms the tray, down foil (foil 1) and PET//PE-EVOH-PE, that forms the closing, upper foil (foil 2).

Film thickness was measured using a micrometer with sensitivity of $0.001 \mathrm{~mm}$. Five thickness measurements were carried out on each film, from which an average was obtained.

Mechanical properties. Prior to the testing of mechanical properties, the films were conditioned for $48 \mathrm{~h}$, at $25 \pm 0.5{ }^{\circ} \mathrm{C}$ and $50 \pm 5 \%$ relative humidity (RH). Tensile strength (TS) and elongation to break (EB) of films were measured on the Instron Universal Testing Instrument Model No 4301 (Instron Engineering Corp., Canton, MA), according to ASTM standard method D882-01 [20].
Water vapor permeability (WVP) was determined gravimetrically according to the ASTM E 96-95 desiccant method [21]. The method involves sealing a known open area of an impermeable container with the film being tested. Anhydrous silica gel was used to maintain $0 \%$ atmosphere inside the cells. Distilled water was used to maintain $100 \% \mathrm{RH}$ outside the cells. Test cells were stored under temperature $23 \pm 2{ }^{\circ} \mathrm{C}$ and weighed periodically until a constant rate of weight gain was reached. Obtained weighting values were used for calculation of the amount of moisture transferred through the film.

Permeability of gasses was measured using method by Lyssy, according to DIN 53380 on the device Lyssy GPM-200 with an appropriate gas chromatograph Gasukuro Kogyo GC-320 and HP 3396 integrator.

Life cycle analysis (LCA) was conducted by using GaBi 4 Education software that allows life cycle assessment.

Statistical analysis. Descriptive statistical analyses for calculating the means and the standard error of the mean, analysis of variance (ANOVA) and post-hoc Tukey's tests were performed using StatSoft Statistica for Windows ver. 10. All obtained results were expressed as the mean \pm standard deviation $(S D)$.

\section{RESULTS AND DISCUSSION}

Thickness determines the mechanical characteristics and essential is for the regular formation of packaging units. The film thickness for layers 1 and 2 samples were $302.50 \pm 4.00$ and $61.90 \pm 0.60 \mu \mathrm{m}$, respectively. The obtained results point to the good uniformity of thickness at all positions.

The mechanical properties of packaging materials and packaging are tensile strength (TS) and elongation at break (EAB). These characteristics are important because they show the benefits of a material for proper application, as well as resistance during transport, handling and storage. Tensile strength and elongation at break of specimens cut longitudinally have twice the value of transversally cut specimens (Table 1 ). The results of tensile strength and elongation at break confirmed the good mechanical properties of tested materials.

Table 1. Tensile strength and elongation at break (mean $\pm S D$ from $N=5$ measurements) for longitudinally and transversally cut foils 1 and 2; different letters printed within the same raw show significantly different means of observed data $(p<0.05)$, 95\% confidence limit, according to post-hoc Tukey's test

\begin{tabular}{lccc}
\hline $\begin{array}{l}\text { Mechanical } \\
\text { properties }\end{array}$ & Sample foil & $T S, \mathrm{~N} / 15 \mathrm{~mm}$ & $E A B / \%$ \\
\hline Longitudinal & 1 & $0.31 \pm 0.01^{\mathrm{d}}$ & $44.90 \pm 13.70^{\mathrm{d}}$ \\
& 2 & $0.21 \pm 0.01^{\mathrm{c}}$ & $6.60 \pm 2.10^{\mathrm{c}}$ \\
& 1 & $0.15 \pm 0.01^{\mathrm{b}}$ & $23.10 \pm 5.90^{\mathrm{b}}$ \\
Transversal & 2 & $0.12 \pm 0.01^{\mathrm{a}}$ & $3.20 \pm 1.00^{\mathrm{a}}$ \\
\hline
\end{tabular}


Results related to water vapour permeability (WVP) $\mathrm{ml} \mathrm{m} / 24 \mathrm{~h}$ were $6.90 \pm 0.19$ and $9.50 \pm 0.06 \mathrm{ml} \mathrm{m}^{-2} / 24$ $h$, respectively, for foils 1 and 2 (mean $\pm S D$ from 5 measurements). According to composition of foil 1 it is obvious that PVC contributes to excellent barrier property (WVP for PVC is $1.5-5 \mathrm{ml} \mathrm{m}^{-2} / 24 \mathrm{~h}$ ). In case of layer 2, WVP of PET and PE are similar [5]. There is a gas permeability through all polymer packaging materials to a lesser or greater extent which determines their usage for packaging of certain food products. Since these materials will be used for modified atmosphere packaging, special attention should be taken to $\mathrm{CO}_{2}$ and $\mathrm{N}_{2}$ permeability. Compared to results obtained by Lazić et al. [22], who analysed similar packed meat products, our results show better properties regarding $\mathrm{CO}_{2}$ and $\mathrm{N}_{2}$ permeabilities.

Results for the permeability of gases are shown in Table 2.

Table 2. Gas permeability $\left(\mathrm{m} / \mathrm{m}^{-2} / 24 \mathrm{~h}\right)$ for foils 1 and 2 samples (mean $\pm S D$ from $N=5$ measurements); different letters printed within the same raw show significantly different means of observed data $(p<0.05), 95 \%$ confidence limit, according to post-hoc Tukey's test

\begin{tabular}{lcccc}
\hline Foil & $\mathrm{CO}_{2}$ & $\mathrm{O}_{2}$ & $\mathrm{~N}_{2}$ & Air permeability \\
\hline 1 & $23.80 \pm 6.90^{\mathrm{a}}$ & $15.50 \pm 7.60^{\mathrm{a}}$ & $0^{\mathrm{a}}$ & $3.60 \pm 2.10^{\mathrm{a}}$ \\
2 & $23.90 \pm 4.00^{\mathrm{a}}$ & $26.00 \pm 0.60^{\mathrm{b}}$ & $26.90 \pm 3.50^{\mathrm{b}}$ & $26.60 \pm 2.60^{\mathrm{b}}$ \\
\hline
\end{tabular}

We collected all necessary data related to the packaging process (capacity of packing machine, machine power, working hours, water and electricity consumption, transport packaging, etc.), distribution, sale, consumption and packaging disposal. Our packaging machine takes both layers to form the packaging, and packs $100 \mathrm{~g}$ of meat product. Afterwards, 12 packs are put into cardboard boxes and form transport packaging. We took into account distribution, sale and meat consumption. The plan considered plastic materials as waste and cardboard boxes as recyclables.

$\mathrm{GaBi} 4$ Education software demands a functional unit to be defined. The functional unit is a quantified unit of the system's function by some physical unit. We declared one packaging as a functional unit so the scaling factor was set to 15000 because of the plant capacity, which was $500 \mathrm{~kg}$ packed meat per day (30 days $\times 500 \mathrm{~kg}=15000 \mathrm{~kg}$ per month).

System boundaries were set as gate-to-gate. This approach of an LCA involves the assessment of the environmental impact of each phase of working life and end of life (EoL) treatment (including recycling and disposal). After connecting individual processes are recorded in the system, the software runs a balance calculation that provides the results.

The first LCA phase consists of calculating the amount of energy and raw materials during the life cycle, and this process gives an inventory of all inputs and outputs (Table 3). The second LCA stage involves the evaluation of the effects of the elements that have impact on the environment, and this is how becomes an environmental load factor (Figures 1 and 2).

Table 3 indicates that among all system flows, air emission has the greatest impact: organic emission (4407.90), followed by emission of heavy metals (2902.30) and inorganic emission (2768.30). Emissions in fresh and sea water and soil are insignificant compared to the emissions into the air. Table 3 shows that power has the largest effect, which actually means the packaging process, because that is the point where the most power is used. An emission reduction proposal would be a modification of the packaging process.

Between many of the parameters that originally belong to the GaBi 4 Education software, we could choose the units we want to represent our results. We chose Human Toxicity Potential and Global Warming Potential as quantities of our process of packaging negative influence on humans and nature. Emissions

Table 3. Total and particular emissions

\begin{tabular}{llccccc}
\hline Process & & Flows & Board boxes & Landfill of plastic Drinking water & Power \\
\hline Emissions to air & Heavy metals to air & 2902.36 & 0.15 & 0.010 & 101.10 & 2801.10 \\
& $\begin{array}{l}\text { Inorganic emissions to air } \\
\text { Organic emissions to air }\end{array}$ & 2768.29 & 0.17 & 0.010 & 12.60 & 2755.51 \\
& $\begin{array}{l}\text { (group VOC) } \\
\text { Particles to air }\end{array}$ & 20.80 & 0.02 & 0.010 & 2.80 & 4405.05 \\
& & 10099.33 & 0.34 & 0.001 & 2.50 & 18.30 \\
Emissions to air (total) & & 88.13 & 0.02 & 0.031 & 119.00 & 9979.96 \\
Emissions to water & Emissions to fresh water & 8.41 & 0 & 0.001 & 2.00 & 86.10 \\
& Emissions to sea water & 96.54 & 0.02 & 0.007 & 2.41 & 8.00 \\
Emissions to water & & 18.62 & 0.01 & 0.001 & 0.01 & 94.10 \\
(total) & & & & & 18.60 \\
Emissions to industrial & & 10214.49 & 0.37 & 0.039 & 121.42 & 10092.66 \\
soil & & & & & & \\
Flows - total & & & & & & \\
\hline
\end{tabular}




\section{GaBi diagram:Meat Modified Atmosphere Packaging - Inputs}

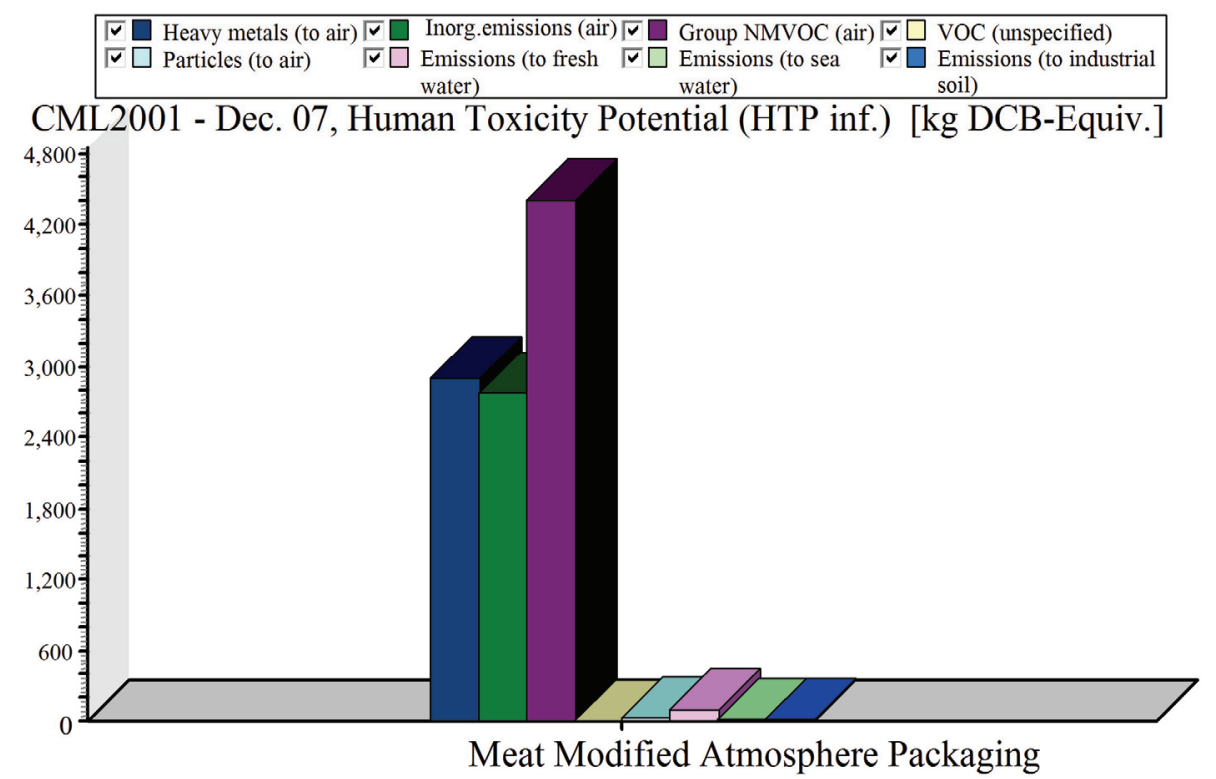

Figure 1. Impact of emissions by using Human Toxicity Potential.

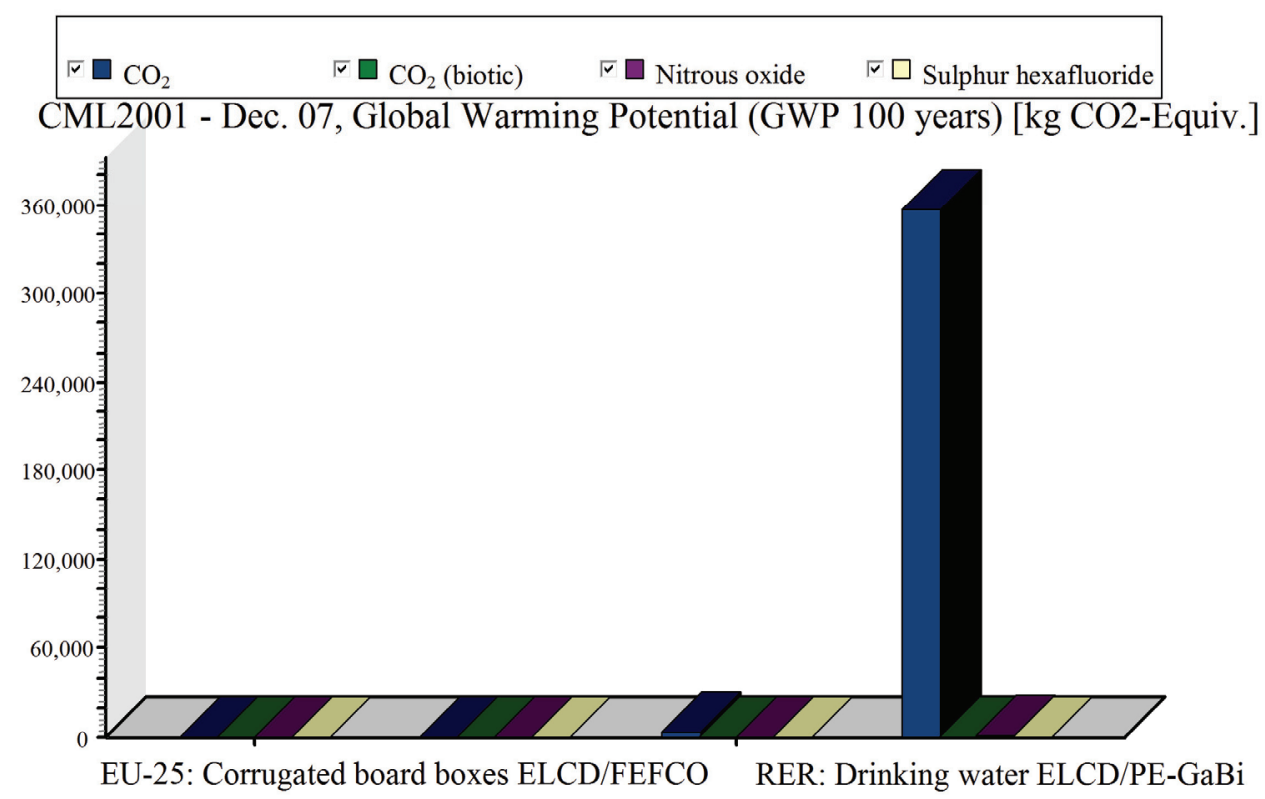

Figure 2. Impact of emissions by using Global Warming Potential.

and impact of emissions are presented in the coming tables and figures.

Result characterization allows us to convert the results in reference units (for example $\mathrm{kg}$ DCB-Equiv or $\mathrm{kg} \mathrm{CO}$ /Equiv.) so that each unit is multiplied by a factor and then all function members summarized and unit of the sum is expresses as $\mathrm{kg} \mathrm{DCB}$-Equiv. or $\mathrm{kg} \mathrm{CO}_{2}$-Equiv.

We used CML2001 - Dec. 07, Human Toxicity Potential (HTP inf., kg DCB-Equiv.) as a quantity in the plan Meat Modified Atmosphere Packaging. By using weak point analysis, the highest impact on human health came from emission to air, especially organic emission to air, which can be seen in Table 3 and Figure 1.

By using CML 2001 - Dec 07, Global Warming Potential (GWP 100 years, $\mathrm{kg} \mathrm{CO}_{2}$ /Equiv.) as a quantity in the plan Meat Modified Atmosphere Packaging, we got further results (Figure 2), which pointed out to $\mathrm{CO}_{2}$ as a main pollutant.

\section{CONCLUSION}

The examined packaging materials can be successfully used on packaging lines of different meat products 
in vacuum or modified atmosphere, which was proven by good mechanical and barrier characteristics. Good mechanical properties are important for good material resistance and proper application. Low values of water vapour $\left(6.90 \pm 0.19\right.$ and $9.50 \pm 0.06 \mathrm{ml} \mathrm{m}^{-2} / 24 \mathrm{~h}$, respectively, for foils 1 and 2 ) and gas permeabilities (less than $30 \mathrm{ml} \mathrm{m}^{-2} / 24 \mathrm{~h}$ for $\mathrm{O}_{2}$ and air) can guarantee that these materials will keep product quality during the declared shelf-life.

Since LCA has been proven to be a useful tool to identify the aspects critical to improve a sustainable production in food industry sector, providing information that can be applied to decision making, we used $\mathrm{GaBi} 4$ Education software, to obtain results related to environmental pollution for our specific case study of meat packaging. It can be concluded that emission to air had the highest impact on human health, especially organic emission to air and $\mathrm{CO}_{2}$ is indicated as a main pollutant in the field of global warming.

\section{Acknowledgement}

This work is part of the project "Osmotic dehydration of food - energy and environmental aspects of sustainable production", project number TR-31055, financed by the Ministry of Education, Science and Technological Development of the Republic of Serbia.

\section{REFERENCES}

[1] A. Dobon, P. Cordero, F. Kreft, S.R. Østergaard, M. Robertsson, M. Smolander, M. Hortal, The sustainability of communicative packaging concepts in the food supply chain. A case study: part 1 . Life cycle assessment, Int. J. Life Cycle Assess. 16 (2011) 168-177.

[2] K. Sonneveld, The Role of Life Cycle Assessment as a Decision Support Tool for Packaging, Packag. Tech. Sci. 13 (2000) 55-61.

[3] R. Cliff, A. Doig, G. Finnveden, The Application of Life Cycle Assessment to Integrated Waste Management. Part 1 - Methodology, Trans. IchemE. 78(B) (2000) 279$-287$.

[4] F.R. McDougall, P. White, M. Franke, P. Hindle, Integrated Solid Waste Management: a Life cycle Inventory, $2^{\text {nd }}$ ed., Blackwell Science, Oxford, 2001.

[5] SETAC, A Conceptual framework for life cycle impact assessment. Pensacola, USA: SETAC (Society of Environmental Toxicology and Chemistry), 1993.

[6] G. Pardo, J. Zufía, Environmental impact of packaging and food losses, J. Clean. Prod. 28 (2012) 198-207.

[7] L.A. Calderón, L. Iglesias, A. Laca, M. Herrero, M. Díaz, The utility of Life Cycle Assessment in the ready meal food industry, Resour. Conserv. Recyc. 54 (2010) 1196$-1207$.

[8] ISO 14040, Environmental Management e Life Cycle Assessment e Principles and framework. International Organization for Standardization, Geneva, 1997.

[9] ISO 14041, Environmental management e Life cycle assessment e Goal and scope definition and life cycle inventory analysis. International Organization for Standardization, Geneva, 1998.

[10] ISO 14042, a. Environmental management e Life cycle assessment e Life cycle impact assessment. Internationnal Organization for Standardization, Geneva, 2000.

[11] ISO 14043, b. Environmental management e Life cycle assessment e Life cycle interpretation. International Organization for Standardization, Geneva, 2000.

[12] M. de Monte, E. Padoano, D. Pozzetto, Alternative coffee packaging: an analysis from a life cycle point of view, J. Food Eng. 66 (2005) 405-411.

[13] L. Shen, M.K. Patel, Life Cycle Assessment of Polysaccharide Materials: A Review, J. Polym. Environ. 16 (2008) 154-167.

[14] P. Roy, D. Nei, T. Orikasa, Q. Xu, H. Okadome, N. Nakamura, A review of life cycle assessment (LCA) on some food products, J. Food Eng. 90 (2009) 1-10.

[15] A. Hospido, M.E. Vazquez, A. Cuevas, G. Feijoo, M.T. Moreira, Environmental assessment of canned tuna manufacture with a life-cycle perspective, Resour. Conserv. Recyc. 47 (2006) 56-72.

[16] J. Zufia, L. Arana, Life cycle assessment to eco-design food products: industrial cooked dish case study, J. Clean. Prod. 16 (2008) 1915-1921.

[17] G.H. Zhou, X.L. Xu, Y. Liu, Preservation technologies for fresh meat - A review, Meat Sci. 86 (2010) 119-128.

[18] A.C. Seydim, J.C. Acton, M.A. Hall, P.L. Dawson, Effects of packaging atmospheres on shelf-life quality of ground ostrich meat, Meat Sci. 73 (2006) 503-510.

[19] K.W. McMillin, Review: Where is MAP Going? A review and future potential of modified atmosphere packaging for meat, Meat Sci. 80 (2008) 43-65.

[20] ASTM D 882-01, Standard test method for tensile properties of thin plastic sheeting. Annual Book of ASTM Standards, Designation D882-01, American Society for Testing Materials, Philadelphia, PA, 2001.

[21] ASTM E 96-95, Standard test methods for water vapor transmission of materials. Annual Book of ASTM Standards, No. E96-95, American Society for Testing and Materials, Philadelphia, PA, 1994.

[22] V. Lazic, N. Krkić, Lj. Petrović, T. Tasić, P. Ikonić, S. Savatić, B. Šojić, Svojstva ambalažnih materijala za pakovanje fermentisanih kobasica pod vakuumom i u modifikovanoj atmosfer, Tehnologija mesa 51 (2010) 95-102 (in Serbian). 


\section{IZVOD}

\section{KARAKTERISTIKE AMBALAŽNIH MATERIJALA ZA PAKOVANJE MESA I PROCENA NJIHOVE EKOLOŠKE PODOBNOSTI}

Danijela Z. Šuput ${ }^{1}$, Vera L. Lazić ${ }^{1}$, Ljubinko B. Lević ${ }^{1}$, Nevena M. Krkić ${ }^{1}$, Vladimir M. Tomović ${ }^{1}$, Lato L. Pezo ${ }^{2}$

${ }^{1}$ Univerzitet u Novom Sadu, Tehnološki fakultet, Novi Sad, Srbija

${ }^{2}$ Univerzitet u Beogradu, Institut za opštu i fizičku hemiju, Beograd, Srbija

\section{(Stručni rad)}

Upotrebljena ambalaža za pakovanje hrane postaje ambalažni otpad koji se gomila i predstavlja ozbiljan problem današnjice, pa je potrebno obratiti pažnju na celokupan životni ciklus ambalaže. Nakon funkcionalne faze (faze upotrebe), ambalaža postaje otpad koji se ili reciklira ili odlaže na deponije. U skorije vreme razvijeni su brojni softveri za procenu rizika ambalaže na životnu sredinu. U ovom radu korišćen je GaBi 4 Education. Kao primer, odabrani su ambalažni materijali koji se koriste $u$ industriji mesa. $S$ obzirom na to da meso i proizvodi od mesa predstavljaju supstrat osetljiv na delovanje spoljašnjih faktora, neophodno ih je tretirati adekvatnim metodama konzervisanja, ali i upakovati u barijerne materijale pod specifičnim uslovima (vakum, MAP). U prvom delu rada je data karakterizacija odabranih ambalažnih materijala u pogledu mehaničkih i barijernih karakteristika. S Obzirom na dobijene niske vrednosti propustljivosti vodene pare, $6,90 \pm 0,19$ i $9,50 \pm 0,06 \mathrm{ml} \mathrm{m}^{-2} / 24 \mathrm{~h}$, redom za folije 1 i 2 , kao i za propustljivosti gasova (vrednosti niže od $30 \mathrm{ml} \mathrm{m}^{-2} / 24 \mathrm{~h}$ za $\mathrm{O}_{2}$ i vazduh), može se zaključiti da su materijali barijerni i da omogućavaju očuvanje vakuma ili zaštitne atmosfere i time doprinose kvalitetu i održivosti proizvoda. $U$ drugom delu rada na odabrane materijale primenjen je GaBi 4 Education softver na osnovu realnih podataka procesa pakovanja, distribucije, prodaje i odlaganja ambalažnog otpada. Softver omogućuje odabir prikaza rezultata kako bi se prikazale kritične tačke životnog ciklusa. Odabran je Human Toxicity Potential i Global Warming Potential kako bi ukazali na to koji parametri najviše utiču na zdravlje ljudi i zagađenje životne sredine. Rezultati su pokazali da na ljudsko zdravlje najviše utiče emisija organskih jedinjenja u vazduh, a da najštetniji uticaj na životnu sredinu ima emisija $\mathrm{CO}_{2}$.

Ključne reči: Ambalaža i pakovanje • Uticaj na životnu sredinu • Proizvodi od mesa 